\title{
Impact of spherical probe scattering on estimation of acoustic vector quantities. (A)
}

Curtis P. Wiederhold

curtis.wiederhold@gmail.com

Kent L. Gee

kentgee@byu.edu

Derek C. Thomas

Scott D. Sommerfeldt

scott_sommerfeldt@byu.edu Follow this and additional works at: https://scholarsarchive.byu.edu/facpub

Part of the Astrophysics and Astronomy Commons, and the Physics Commons

\section{Original Publication Citation}

Wiederhold, C. P. Gee, K. L D. C. Thomas, S. D. Sommerfeldt, and J. D. Blotter (29). Impact of spherical probe scattering on estimation of acoustic vector quantities. The Journal of the Acoustical Society of America 125 (4), 2636. The definitive version of this abstract can be found at: Hhttp://scitation.aip.org/getpdf/servlet/ GetPDFServlet?filetype=pdf\&id=JASMAN125426363\&idtype=cvips\&prog=search

\section{BYU ScholarsArchive Citation}

Wiederhold, Curtis P.; Gee, Kent L.; Thomas, Derek C.; Sommerfeldt, Scott D.; and Blotter, Jonathan D., "Impact of spherical probe scattering on estimation of acoustic vector quantities. (A)" (2009). Faculty Publications. 138.

https://scholarsarchive.byu.edu/facpub/138

This Peer-Reviewed Article is brought to you for free and open access by BYU ScholarsArchive. It has been accepted for inclusion in Faculty Publications by an authorized administrator of BYU ScholarsArchive. For more information, please contact ellen_amatangelo@byu.edu. 


\title{
Impact of spherical probe scattering on estimation of acoustic vector quantities. (A)
}

\author{
J. Acoust. Soc. Am. Volume 125, Issue 4, pp. 2636-2636 (April 2009) \\ Issue Date: April 2009 \\ Curtis P. Wiederhold \\ Dept. of Mech. Eng., Brigham Young Univ., 435 Crabtree Bldg., Provo, UT 84602, \\ curtis.wiederhold@gmail.com
}

Kent L. Gee, Derek C. Thomas, and Scott D. Sommerfeldt

Brigham Young Univ., Provo, UT 84602

Jonathan D. Blotter

Brigham Young Univ., Provo, UT 84602

Multimicrophone probes are often used to measure energy-based acoustical quantities. In some cases, these probes consist of microphones mounted on the surface of a sphere, which, due to the high level of symmetry, permits scattering effects to be better characterized. Scattering of a plane wave incident on a rigid sphere has been modeled to observe how particle velocity and intensity calculations are affected by the presence of the sphere. These effects have been investigated for the traditional "finite-difference" method and a recently developed "wave vector" estimation method. In the computer model, 3-D surface plots were made showing the calculated error as a function of angle of the incident plane wave and frequency. It is shown that using the wave vector method and purposefully orienting the probe in the planar sound field generally results in the most accurate measurements. [Work supported by NASA Stennis Space Center and STI Technologies.]

(C2009 Acoustical Society of America

Wiederhold, C. P., K. L. Gee, D. C. Thomas, S. D. Sommerfeldt, and J. D. Blotter (2009). Impact of spherical probe scattering on estimation of acoustic vector quantities. The Journal of the Acoustical Society of America 125 (4), 2636. The definitive version of this abstract can be found at:

http://scitation.aip.org/getpdf/servlet/GetPDFServlet?filetype=pdf\&id=JASMAN000125000004 002636000003\&idtype=cvips\&prog=search 